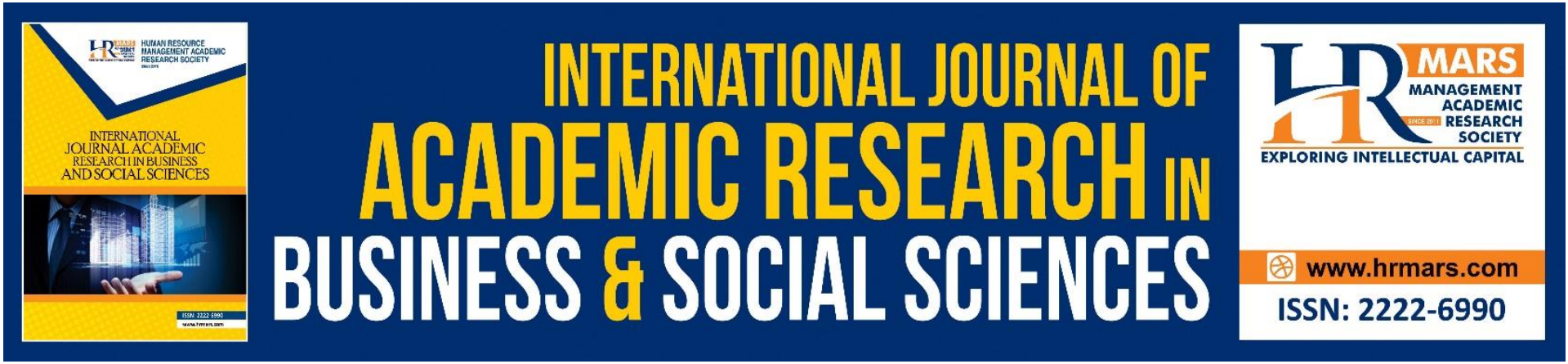

\title{
Review of the IT Integration Framework for a University's Institutional Performance Setting in Zimbabwe
}

\author{
Precious Kahwema and Taisir Hameed
}

To Link this Article: http://dx.doi.org/10.6007/IJARBSS/v12-i1/12054

DOI:10.6007/IJARBSS/v12-i1/12054

Received: 06 November 2021, Revised: 08 December 2021, Accepted: 23 December 2021

Published Online: 05 January 2022

In-Text Citation: (Kahwema \& Hameed, 2022)

To Cite this Article: Kahwema, P., \& Hameed, T. (2022). Review of the IT Integration Framework for a University's Institutional Performance Setting in Zimbabwe. International Journal of Academic Research in Business and Social Sciences, 12(1), 353-384.

Copyright: @ 2022 The Author(s)

Published by Human Resource Management Academic Research Society (www.hrmars.com)

This article is published under the Creative Commons Attribution (CC BY 4.0) license. Anyone may reproduce, distribute, translate and create derivative works of this article (for both commercial and non0-commercial purposes), subject to full attribution to the original publication and authors. The full terms of this license may be seen at: http://creativecommons.org/licences/by/4.0/legalcode

Vol. 12, No. 1, 2022, Pg. $353-384$

Full Terms \& Conditions of access and use can be found at http://hrmars.com/index.php/pages/detail/publication-ethics 


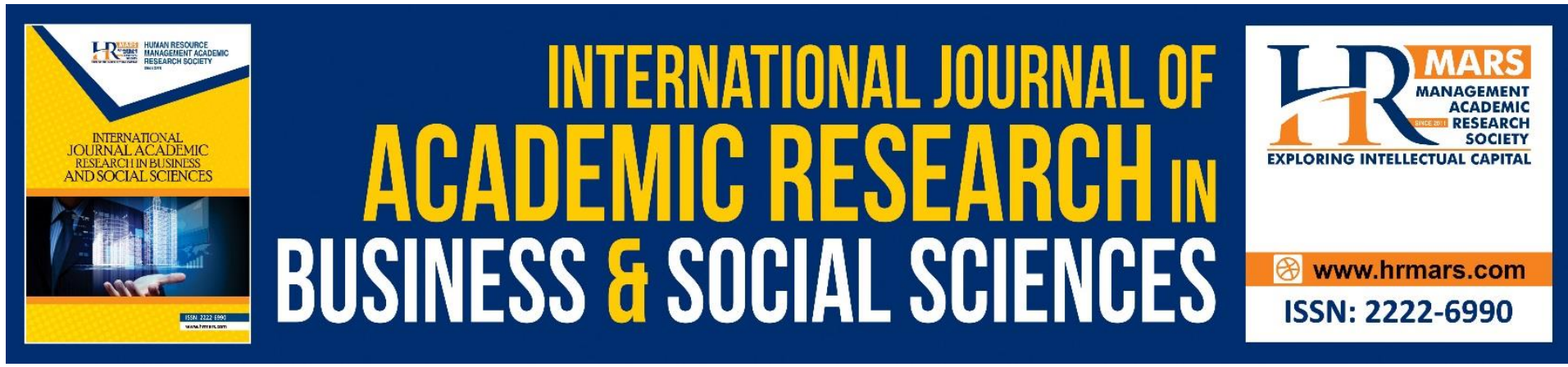

\title{
Review of the IT Integration Framework for a University's Institutional Performance Setting in Zimbabwe
}

\author{
Precious Kahwema ${ }^{1}$ and Dr. Taisir Hameed ${ }^{2}$ \\ ${ }^{1}$ DBA Researcher, Binary University of Management \& Entrepreneurship, Malaysia and \\ ${ }^{2}$ Lecturer, Binary University of Management \& Entrepreneurship, Malaysia
}

\begin{abstract}
The use of Information and Communication Technologies (ICTs) in the 21st century organizations have a great impact on efficient management of operations, improved decisionmaking capabilities, leveraging competitive advantage, and facilitation of seamless integration and communication with key stakeholders. E learning, which is premised on ICTs, has become a defacto standard mode of delivery in the face of the Covid 19 pandemic. The purpose of the qualitative study was to review the Information Technology framework for University Institutional performance and determine how technology was being integrated in the teaching/learning process in a university setting. It is envisaged to develop a technology roadmap for business administration of a university setting. In this research, a qualitative research methodology was used to fulfil the objectives of this study. The research design was mainly an evaluation and then supported by a brief case study. The research paper reviewed IT integration framework premised on ten theories, namely, the Innovations Diffusion Theory; the Technology Acceptance Model (TAM); Innovator's Solution Theory; Unified Theory of Acceptance and Use of Technology (UTAUT); Resource Based Theory; Theory of Reasoned Action (TRA); the Technology-Organisation-Environment (TOE) framework; Benefits, organizational readiness and external pressure (BOE) model; the Theory of Planned Behaviour (TPB); and the Technological Pedagogical Content Knowledge (TPACK) framework. The IT integration framework was reviewed in the context of enhancing institutional performance of a university. The brief case study was conducted at selected national Universities to conclude the study.
\end{abstract}

Keywords: ICT, IT Integration, TAM.

\section{Introduction}

\section{Background}

According to the Zimbabwe Council of Higher Education (ZIMCHE), Zimbabwe now has 24 registered Universities - 14 state (public) and 10 privates, and all these Universities have total enrollments of up to 130,000 students and employs 20,000 people. The common challenge facing each of these Universities is on the ability to drive the University (leadership), grow the university (market reach and resource mobilization) and depict the positive image of the university. Most of the newer universities have inadequate infrastructure and high cost of 
capital. However, there is a consensus on the great need for STEM programmes and cuttingedge skills to produce technological solutions for industrialization and modernization in line with the Education 5.0 national policy. The key business problem is on achieving University Institutional performance in an increasingly networked environment. A networked environment in this context is inclusive of connected nodal networks, blended learning, distance learning, asynchronous / synchronous learning, computer supported collaborative learning, community of learning, teachers and students, interactive learning (between learners, between learners and teachers, between learners and content), co-creative, collaborative, inclusive spaces, participatory learning context and spaces, time on task, feedback mechanism (learner, group, country), learner analytics, and integrated tutoring systems. ZIMCHE has been championing introduction of Minimum Body of Knowledge and Skills (MBKS) in all national Higher Education Institutions as a way of standardizing the curriculum. ZIMCHE accredits only those University programmes that meet ZIMCHE's minimum agreed standards with respect to the following (ZIMCHE Annual Report, 2018, p.13):

* Relevant and well-crafted curriculum that addresses the HEl's mandate and the national needs

* Adequate financial resources

* Teaching and learning facilities

* Availability of the relevant electronic and hard copy reading material

* Adequate ICT provision

* Appropriately qualified teaching staff

Through Information and communications technologies (ICT) as an enabler, companies can provide products and services of the highest quality at affordable prices, excellent customer service, penetration of new markets through e-commerce, global collaborations, improvement of productivity, and stakeholder satisfaction. Information Technology integration is a very challenging complex process for a university teaching and learning setting, particularly in a university environment that has had financial limitations on investment in technology and where there has been limited skills and competences in the use of ICTs in support of teaching and learning. Information Technology (IT) Integration includes the advancement and reconfiguration of information technology (IT) to re-enforce business systems. Information technology integration results in a positive impact on performance following the use of IT tools in business operations strategy (Alshamsi, et al., 2020; Kim and Keller, 2011). The Strategic Balanced score card connects all the key elements of a firm's strategy to achieve both financial and non-financial measures with respect to customer, financial, innovation and learning, and internal business perspectives. The purpose of the qualitative study was to review the Information Technology framework for University Institutional performance, and determine how technology was being integrated in the teaching/learning process in a university setting. IT integration framework reviewed is premised on nine theories, namely, the Innovations Diffusion Theory; the Technology Acceptance Model (TAM); Innovator's Solution Theory; Unified Theory of Acceptance and Use of Technology (UTAUT); Resource Based Theory; Theory of Reasoned Action (TRA); the Technology-Organisation-Environment (TOE) framework; Benefits, organizational readiness and external pressure (BOE) model; the Theory of Planned Behaviour (TPB); and the Technological Pedagogical Content Knowledge (TPACK) framework. 
Information and Communications Technologies (ICT) are equally required in the provision of administrative support and the teaching/learning process of a modern University. The factors that frustrate IT integration into the classroom include the lack of access to computers, software, planning time and administrative support (Ertmer, 2008). Obviously, without the correct number of resources it would be difficult for educators to effectively implement and use technologies within the pedagogy.

\section{Technological Dynamics}

a) Modular Object-Oriented Dynamic Learning Environment (Moodle) is a powerful learning management system that allows users to engage in synchronous or asynchronous online learning experiences. These learning experiences could be structured into online courses or could promote informal forms of learning as one find in some online communities of practice. The open-source facility means that users have access to the source code of the software and so a user can write new features, improve the design and look at how others have found solutions to problems (Cole, 2005). 'Moodle's design philosophy makes this a uniquely teacher-friendly package that represents the first generation of educational tools that are truly useful' (Cole, 2005 p. 5).

b) Big Data came into existence when the traditional relational database systems were not able to handle the unstructured data generated by organizations, social media, or from any other data generating source (Siti et al, 2017). According to Wilson et al (2015), Big Data refers to the flood of digital data from many digital sources. The data types include images, geometries, texts, videos, sounds and combinations of each. Hashem et al (2015) explained big data as the increase in volume of data that offers difficulty in storage, processing and analysis through the traditional database technologies.

c) Cyber security consolidates the confidentiality, integrity, and availability of computing resources, networks, software programs, and data into a coherent collection of policies, technologies, processes, and techniques to prevent the occurrence of an attack (Berman et al, 2019). Cyber security refers to a combination of technologies, processes and operations that are framed to protect information systems, computers, devices, programs, data and networks from internal or external threats, harm, damage, attacks or unauthorized access for example ransom ware, denial of service attacks (Lei et al, 2019). The rapid advances in mobile computing, communications and mass storage architectures have precipitated the new phenomena of Big Data and Internet of Things (IOT). Outsider and insider threats can have serious implications on an institution for example, failure to provide services, higher costs of operations, loss in revenue, and reputational damage (Gheyas and Abdullah, 2016; Lei et al, 2019). Therefore, an effective cyber security model must be able to mitigate cyber security events such as unauthorized access, zero day attack, denial of service, data breach, malware attacks, social engineering (or phishing), fraud and spam attacks, through intrusion detection and malware detection (Kantarcioglu and Xi, 2016; Sarker et al., 2020).

\section{Statement of the Problem}

The main problem of a typical Zimbabwean University during the COVID-19 era is the relatively low scholarship throughput coupled with weak marketing positioning. The key 
business problem is on achieving University Institutional performance in an increasingly networked environment where E learning, which is premised on ICTs, has become a defacto standard mode of delivery. Information Technology (IT) Integration includes the advancement and reconfiguration of Information Technology (IT) to re-enforce business systems and improve on the University Institutional performance. Organizational performance is a comparison of actual output as measured against the expected outputs as detailed by an institution's goals and objectives. The Strategic Balanced score card connects all the key elements of a firm's strategy to achieve both financial and non-financial measures with respect to customer, financial, innovation and learning, and internal business perspectives. The purpose of the qualitative study was to review the Information Technology framework for institutional University performance, and determine how technology was being integrated in the teaching/learning process in a university setting. The ICT revolution, at organizational and global level, requires high-level technological competences, extensive investments into the infrastructure and equipment, and adoption of the technologies for efficient and effective business management. Businesses currently face complexity in managing future projections, sound resource management, organizational performance, corporate governance, data analytics, ability to attract and retain staff, and attainment of excellent customer service and satisfaction.

\section{Purpose of Study}

The purpose of the qualitative study was to review the Information Technology integration framework/theories for institutional University performance, and determine how technology was being integrated in the teaching/learning process in a university setting. It is envisaged to develop a technology roadmap for business administration and institutional performance of a university setting.

\section{Research Objectives}

The research objectives are to:

a) Evaluate the relationship between IT integration and University institutional performance, and

b) Identify the technological gap in business administration and the teaching/learning process in a typical Zimbabwean University.

\section{Research Questions}

The main research question was:

- What is the foundational framework underlying the IT integration for University Institutional performance from an administrative and teaching/learning perspective?

The sub questions are:

a) What is the foundational framework for IT integration in support of University Institutional performance?

b) What is the technology gap in the business administration and the teaching/learning process of a university setting? 


\section{Literature Review \\ Corporate Performance}

Corporate performance is a measure of performance of how well an organization executes on the strategic decisions implemented and other important parameters. Performance is therefore a comparison of actual output as measured against the expected outputs as detailed by an institution's goals and objectives. According to Richard et al. (2009), corporate performance constitutes three main aspects namely financial (profits, return on investment, return on assets, etc.), product market performance (market share and sales.) and shareholder returns. Campanella et al (2020) agrees that return on investment also defines corporate performance and further asserts that banks characterized by high level of organizational ambidexterity usually have high return on equity owing to factors like research and development. Mojambo et al (2020) defines corporate performance from a different perspective of the type of management that an organization has. An organization becomes a reflection of its management, hence it performs in alignment with its type of management. Generally, according to Makanyeza (2017) the financial performance of an institution refers to how well it utilises its assets and generate revenues.

\section{THE Innovation Diffusion Theory}

The diffusion of innovations theory was developed by Everett $M$ Rogers and it investigates the characteristics of adopters of innovative technology as well as how a new idea or product gains momentum in a particular social system. The theory is premised on five crucial factors namely relative advantage (of new technology), triability (trial and error before adoption), observability (of outputs and gains of the technology), complexity (ease of use) and compatibility (with systems). According to Rogers (2003), the cycle categorises technological innovation adopters into innovators, early adopters, early majority, late majority and laggards.

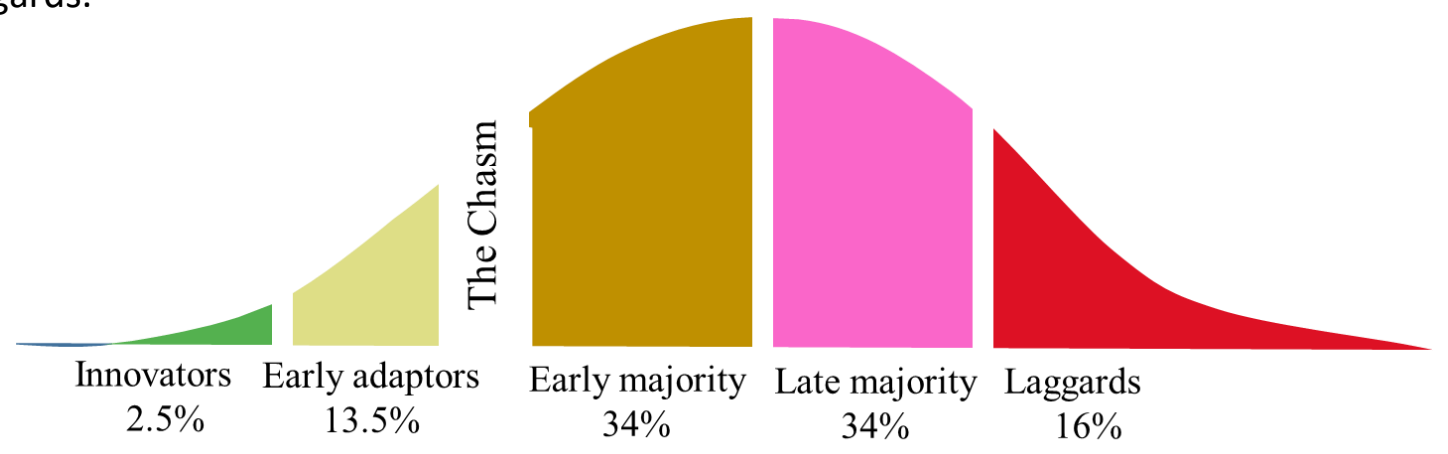

Figure 1. Innovation Adoption Curve (Roger, 2003:281)

According to Dasgupta and Wendler (2019) this model describes the diffusion of technology, and the factors that influence it. Rogers (1995) posited that the theory originates from communication to explain how an idea or product gains momentum and spreads through a particular population or social system over time. This theory therefore indicates that innovation should be widely adopted to achieve development and sustainability. Rogers (1995) argues that people who adopt an innovation early have different characteristics than people who adopt an innovation later. Roger (1995) classifies adopters into five categories of innovators, early adopters, early majority, later majority, and laggards. He further indicated that strategies for different categories of adopters should be different when promoting innovation. 
Gouws and George (2011) concur with the assertion that late majority and laggards is comprised of such shop floor workers who are more traditional, poorer, lower status individuals for whom peer pressure plays a role in the adoption process. The category comprises skeptical users who prefer to wait until most of the others have adopted, they always doubt the new technology and in the case of laggards they are always resistant to change based on past failure trends or the reasons that the new innovation will take away their jobs such as data capturers in academic registry and banks.

Despite all the contributions presented above, Damsgaard (2011) argued that the theory is very much outdated and does not apply to modern day environment. She indicated that the model revolves around the fact that the diffusion process often originates from the top management and that is where the technological ideas are centered. This is not always the case because some of the innovations can originate from the shop floor workers who will be on the ground regarding day-to-day operations hence the diffusion process can be a bottom to top approach.

Technology Diffusion theory acknowledges the presence of ICT within organizations which validates the importance of the theory with regards to the study area. Moore (2016), however pointed out that it is only concerned about how the aspect of technology is transferred from one person to the other across various departments within a given organization and the importance of it to organizations and societies in general. The theory however does not stress the effective role that the subject plays within organizations such as banks in which the study aims to focus on that gap.

\section{The Technology Acceptance Model (TAM)}

The Technology Acceptance Model (TAM) was developed by Davis (1985) based on the theory of reasoned action (TRA) conceptualized by Fishbein and Ajzen's (1975). The TRA is applicable to any specific domain of human-computer interactions and the TAM expounds on this theory by providing a theoretical linkage among users' internal beliefs, attitudes, intentions, and usage behavior (Davis, 1989). The theory looks at the attitude, perception and intention to utilize the introduced technology and the influencing factors on how and when to use the technology.

Accordingly, the TAM provides the framework for exploring the key determinants associated with the communication technology adoption behaviors of social workers (Davis et al., 1989). The TAM posits that the outcome of an individual's emotional response toward a technological innovation constitutes technology adoption behavior. The TAM examines user acceptance of technology and shows the relationship between perceived usefulness $(U)$, perceived ease of use (EOU), behavioral intentions to use (BI), and the actual system use. Perceived usefulness refers to the extent to which an individual believes that his / her job would be enhanced from the use of a system or innovation. Perceived ease of use is the extent to which an individual deems that by using a system he / she would be freed of some effort. The TAM predicts further that user acceptance behaviors of technology are based on the influences of two key determinants: $U$ and perceived EOU.

\section{i. Perceived Usefulness (U) and Perceived Ease of Use (EOU)}

Perceived Usefulness $(U)$ is the degree to which an individual believes on the ability to enhance job performance within the organization context based on a particular system (Davis 
et al., 1989). EOU is the degree to which an individual believes that a particular system will be free of mental effort as they use a particular system (Davis et al., 1989). There is a clear distinction between $\mathrm{U}$ and EOU although there are related concepts.

\section{ii. Perceived Usefulness (U)}

Mishna et al. (2012) examined how online communication, such as email, text messages, and social networking sites, are being integrated into face-to-face social work practice and found that when communication technologies were used for administrative purposes. However, when communication technologies were used for nonadministrative purposes, social workers believed that professional boundaries could potentially become blurred because no clear standards related to communication technology had been established (Mishna et al., 2012). For example, because of the perceived usefulness of new technologies, many social workers may receive requests from current or former clients asking to be social networking "friends" or contacts. Moreover, one of the greatest challenges toward integrating communication technology into social work practice is the emergence of e-counseling and e-therapy (Csiernik et al., 2006).

The TAM is illustrated on Figure 2 below.

Figure 2: Technology Acceptance Model (Source: Scherer et al., 2019)

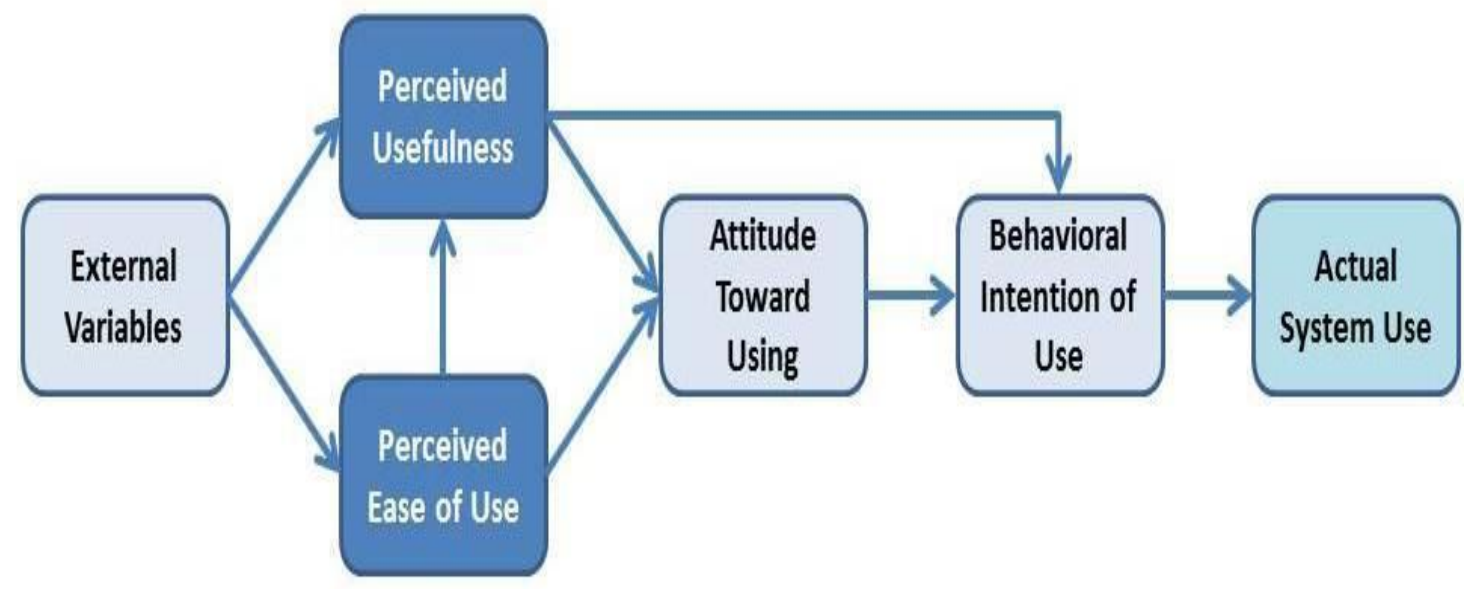

iii. Ease of Use (EOU)

Poor implementation and lack of training of technological tools has also been cited as an explanation for social workers' resistance to technology (Baker, Warburton, Hodgkin \& Pascal, 2014).

\section{iv. Behavioral Intentions (BI)}

Usually, social workers consider technology to be complex systems that contribute to diminishing the client-worker relationship (Reardon, 2010).

Aypay et al (2012) put the theory to test in the predicting the intensity of technology acceptance amongst pre-service teachers and the results highlighted that there is a relationship between the model and technology acquisition. In addition, Garg (2013) asserted that in formulating perceptions regarding new technologies, subjective and social norms influence consumers as well as perceptions of the quality of service. 
Despite the contributions that Technology Acceptance Model has provided, Chattur (2015) indicated that the model has several short comings. He stated that academies are doubting the application and the theoretical precision of the model, hence it is persuasive to conclude that the research on the model may have reached its saturation stages. He suggested that there is need for future scholars to focus on developing new models that would take advantage of the strength of the model whilst discarding its weaknesses. Durodolu (2016) also noted that the model is inadequate in explaining the adoption of technology ignoring the societal influence that dictates technology adoption. It is shallow to analyze the adoption of technology from an individual perspective because factors like environment, society, economic status within the vicinity where technology is exposed to individual can collectively have an impact on the adoption and use, hence one cannot as well compare determinants of banking environment and that of food chain industry.

\section{Innovator's Solution Theory}

The innovator's solution theory by Christensen and Raynor (2013) is an analysis that shows the reasons why organizations and institutions fail to innovate. The theory crystalizes why management within corporates do not learn about good ideas and often cannot stand competitive pressure that result from disruptive innovations from their counterparts. Due to the competitive pressure rushed short term decisions with undesirable long term consequences are usually made (Anthony, 2008). Effective diagnosis on why the company fails to adopt disruptive innovation is normally undertaken but however it remains less helpful as the company is inherently and constitutionally disinclined to handle disruptive innovation. According to the theory the solution then becomes the dire need to safeguard genuine innovators and their ideas from the dangerous innovation killing forces aforementioned. Christensen and Raynor (2008) propounds that leadership should therefore erect a wall between innovation and the existing leadership hierarchy through having an independent unit that will safeguard innovations. Such a move will ensure innovations find their way into the company without hierarchical obstructions although it eventually leads to culture and power clashes. This theory is very useful for the current study and together with the technology acceptance model and innovation diffusion theory helps explain why certain popular financial technological innovations are yet to get into mainstream banking of many developing nations owing to barriers that have been put forward such as existing leadership.

\section{Unified Theory of Acceptance and Use of Technology (UTAUT)}

This is a technology acceptance model propounded by Venkatesh, (2000) and others in "Client acknowledgment of data innovation: Toward a bound together view. The UTAUT means to disclose client aims to utilize a data framework and resulting utilization conduct. The hypothesis holds that four key builds: execution anticipation, exertion hope, social impact, and encouraging conditions; the initial three being immediate determinants of utilization aim and conduct, and the fourth an immediate determinant of utilization conduct. Sexual orientation, age, understanding, and intentionality of utilization are placed to direct the effect of the four key builds on use expectation and conduct. Venkatesh, et al (2008) thinks that the purpose of UTAUT model is to offer the manager with using tools, the manager can use UTAUT to weigh the introduction of new technology and predict and explain the user's behavior of accepting Information and Communications Technology. From previous empirical test results, Koivumäki et al (2008) found that the explanatory power of this UTAUT model is up to $70 \%$ with regard to technology using behavior. 
The theory was established on four theoretical constructs representing determinants of Intention to Use or Usage Behaviour, which play essential roles as surrogates of Technology Acceptance (Parasuraman \& Colby , 2001).Venkatesh, Moris, Davis and Davis (2003) developed the Unified Theory of Acceptance and Use of Technology (UTAUT) shown in Figure 3. The UTAUT (Figure 3) has use behaviour (UB) as the main variable, which Venkatesh et al. defined as the degree to which a person accepts and uses a new technology. According to Figure $3, \mathrm{UB}$ is a function of behavioural intention (BI) and facilitating conditions ( $\mathrm{FC}$ ). $\mathrm{BI}$ is a measure of the strength of one's intention to perform a specific behaviour (Davis et al., 1989), while FC is the degree to which an individual believes that organisational and technical infrastructure required for the support of the technology exists (Venkatesh et al., 2003).

$\mathrm{BI}$ is in turn, as illustrated in Figure 3, determined by performance expectancy (PE), effort expectancy (EE) and social influence (SI). Venkatesh et al (2003) defined PE as the degree to which an individual may attain job performance using the technology; EE as the degree of ease associated with the use of the technology; and SI as the degree to which an individual perceives that important others believe that he or she should use the technology.

Figure 3: The Unified Theory of Acceptance and Use of Technology (UTAUT) Model Source: Venkatesh et al. (2003), page 447, Figure 3.

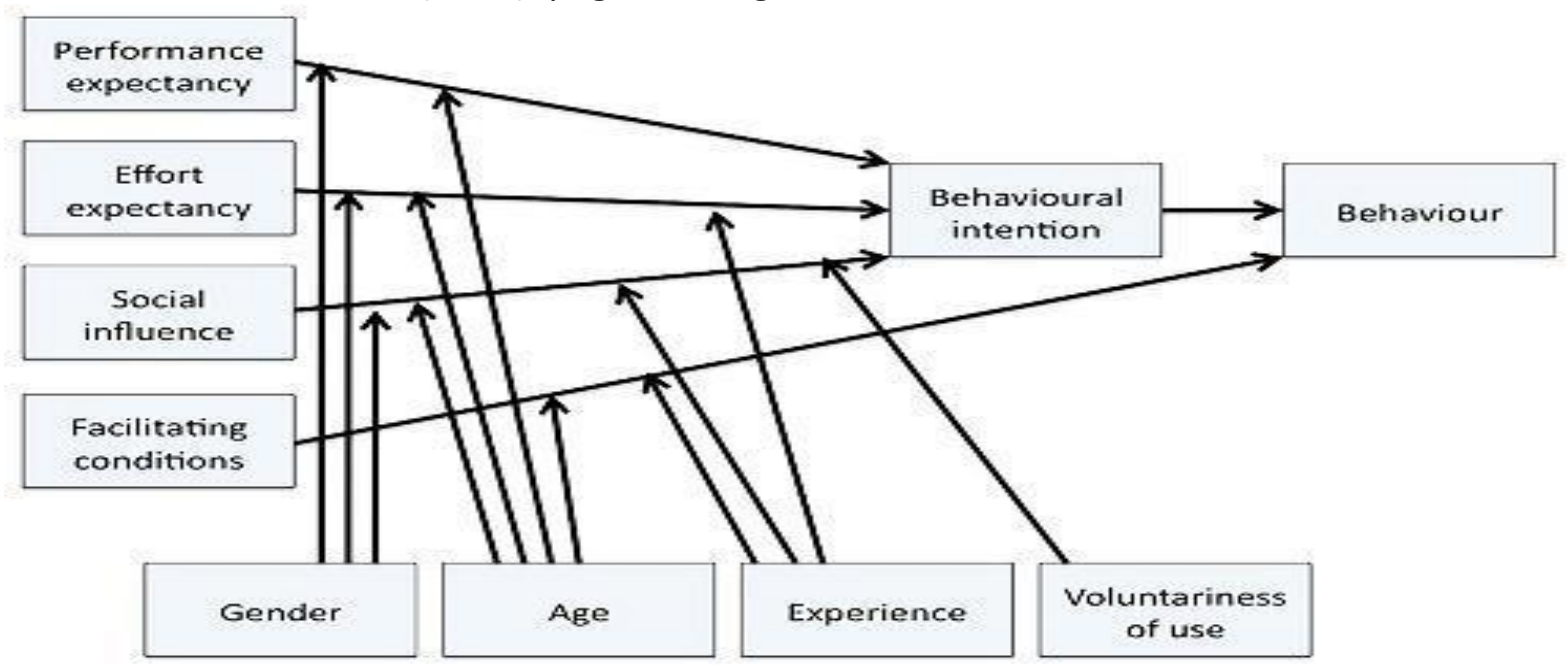

In developing the UTAUT, Venkatesh et al. based on eight technology acceptance theories or models, which included TRA, TAM and TPB which have been reviewed in this paper. Hence, Dwivedi et al. reported that PE had shown the strongest correlation with $\mathrm{BI}$ followed by $\mathrm{SI}, \mathrm{EE}$ and $\mathrm{FC}$ throughout the studies they reviewed. Such findings suggest that most researches on UTAUT had not used the dependent variable (UB) as the model (Figure 3) requires. Instead they had used BI which is just a moderating variable in the UTAUT model. This is a glaring gap that warrants attention by future researchers. They identified another gap to the effect that most empirical studies they reviewed on the UTAUT model had been more of quantitative than qualitative and mixed approaches.

\section{Resource Based Theory (RBT)}

The Resource Based Theory (RBT) relies on two core assumptions about firm-based resources and how to enhance firm performance. Whereas 'resources' refers to the tangible and 
intangible assets (e.g., technology, human \& organizational), 'capabilities' are subsets of the firm's resources which are non-transferable and aim to enhance the productivity of other resources (Makadok, 1999). Capabilities can be identified as tangible or intangible processes that facilitate deployment of other resources and enhance overall productivity. This study suggests RBT as a compelling framework for integrating dissimilar BDAC dimensions, their synergistic effects on FPER and the contingency of business strategy alignment associated with this overall capabilities-performance relationship. Kim et al. (2012) defined firm performance as "A firm's competence to change existing business processes better than competitors do in terms of coordination/ integration, cost reduction, and business intelligence/learning".

\section{Theory of Reasoned Action (TRA)}

Ajzen and Fishbein (1980) developed the Theory of Reasoned Action (TRA) shown in Figure 4. According to Figure 4, the TRA model has actual behaviour (AB) as its main variable. As per Figure 4, $A B$ is postulated to be determined by behavioural intention (BI). According to Ajzen and Fishbein, ATB is the degree to which a person has a favourable or unfavourable evaluation or appraisal of the behaviour in question, whilst $\mathrm{SN}$ is the perceived social pressure to perform or not to perform the behaviour. As per Figure 4, TRA theorises that SN is influenced by normative beliefs and motivation to comply (nbmc).

Figure 4: The Theory of Reasoned Action

Source: Ajzen and Fishbein (1980), page 17, Figure 1.2

\section{Theory of Reasoned Action (TRA)}

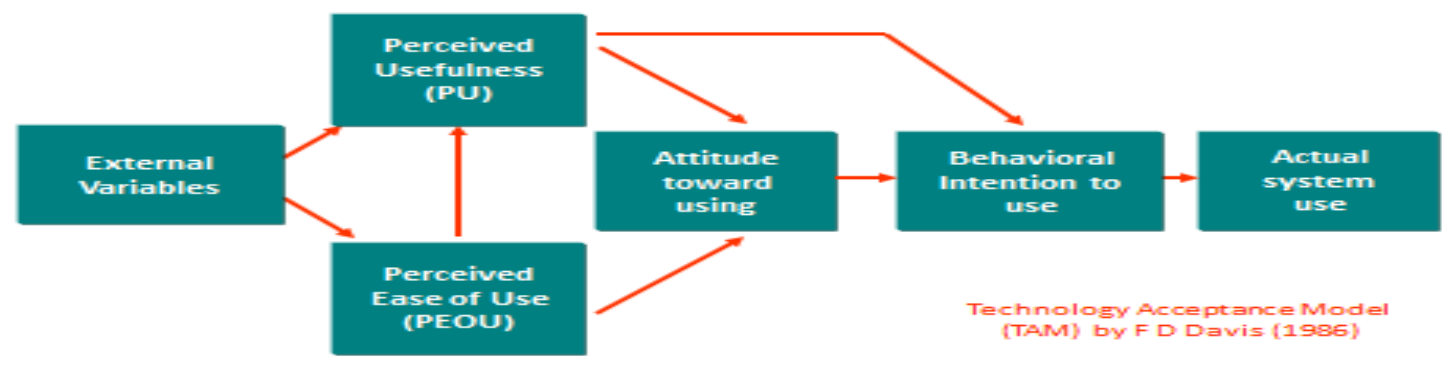

Technology-Organisation-Environment Framework (TOE)

Tornatzky and Fleischer (1990) developed the Technology-Organisation Environment (TOE) framework shown in Figure 5. The TOE framework (Figure 5) theorises that technological adoption decision making, the main variable, is influenced by three principal contexts namely; the technological, organizational and environmental.

Figure 5: Technology-Organisation-Environment (TOE) framework Source: Tornatzky \& Fleischer (1990), page 32, Figure 3-1. 


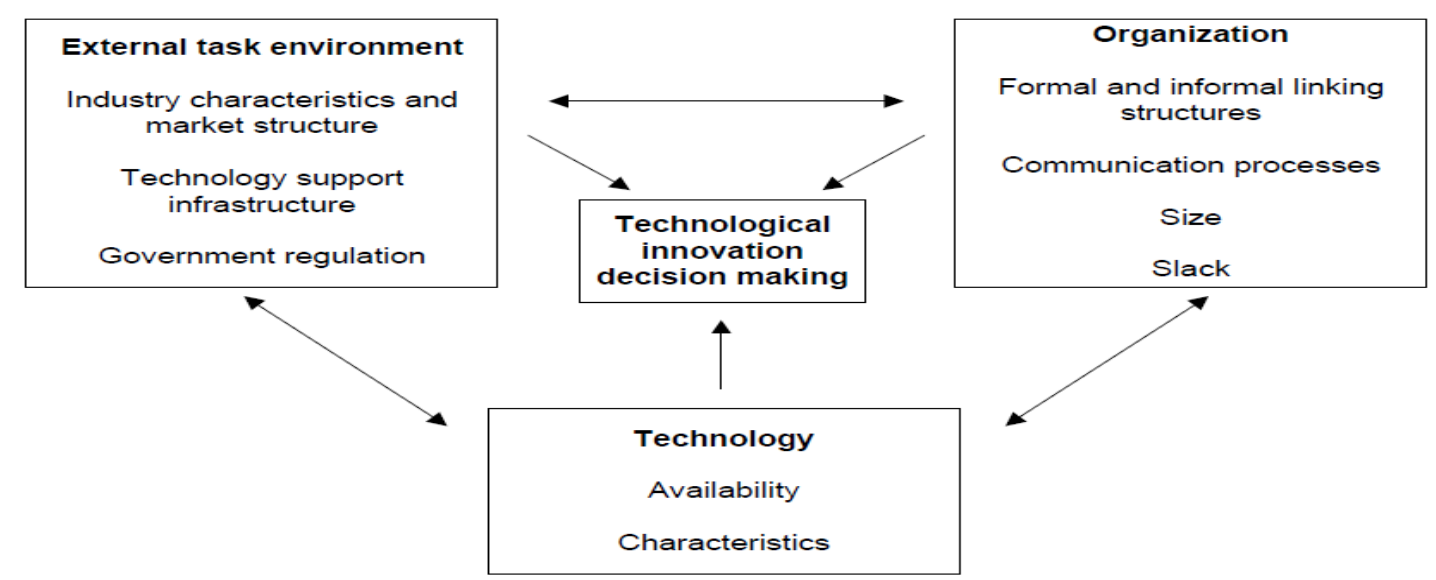

Tornatzky and Fleischer (1990) defined the technological context as the internal and external technologies that are relevant to the organisation and according to them, may include both equipment as well as processes. Tornatzky and Fleischer observed that adoption of an innovation depends on the pool of technologies inside and outside an organisation as well as the perceived characteristics (e.g. relative advantage, compatibility, complex, triability, and observability) of the innovation. The organizational context are the characteristics and resources of the organization such as managerial support, organisational culture and size, communication processes, and the amount of slack resources an organisation has (Tornatzky \& Fleischer, 1990). The environmental context as Figure 5 suggests, is the setting in which the organisation conducts its business. According to the TOE framework the environmental context includes the organisation itself, market scope, competitive pressure, technology support infrastructure and regulatory environment.

This theory describes the factors "for" technological adoption, focusing on the external pressures (for example market forces and government regulation), organisational structures, and technological availability (Dasgupta and Wendler, 2019). According to Tornatzky and Fleisher (1990), the technological context includes the internal and external technologies that are relevant to the firm, organizational context refers to the characteristics and resources of the firm and the environmental context comprises market elements, competitors, and the regulatory environment.

Yang, Kankanhalli, Ng and Lim (2013) support that the technology, organisation, and environment context (TOE) model is viewed as a more comprehensive lens for the study of the adoption of technological innovations at the organisation level.

\section{Theory of Planned Behaviour (TPB)}

The Theory of Planned Behaviour (TPB) as shown in Figure 4, was developed by Ajzen (1991), and has actual behaviour $(A B)$ as the main variable. $A B$ was defined by Ajzen with respect to a given target as an individual's observable response in a given situation. According to Figure 7, TPB theorises that $A B$ is predicted by both behavioural intention (BI) and perceived behavioural control (PBC). Ajzen defined $\mathrm{BI}$ as an indication of a person's readiness to perform a given behaviour and $\mathrm{PBC}$ as the perceived ease or difficulty of performing the behaviour. Ajzen (1991) defined control beliefs (cb) as a perception of the availability of skills, resources and opportunities; and perceived facilitation (pf) as the individual's assessment of the importance of those resources to the achievement of outcomes. Ajzen (1991) observed that TPB (Figure 7) extended TRA (Figure 1) by incorporating PBC as a set of factors that affect BI and $A B$. 
Figure 7: The Theory of Planned Behaviour (TPB)

Source: Ajzen (1991), page 182, Figure 1.

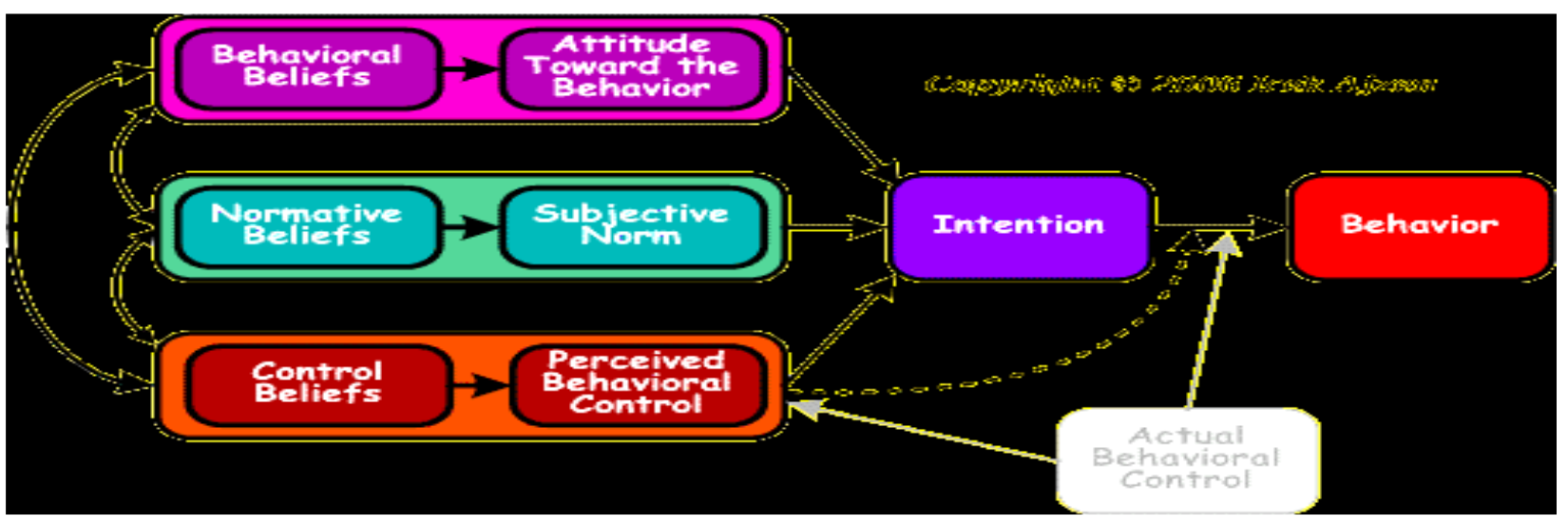

Notani's (1998) meta-analysis examined the role of perceived behavioural control (PBC) in predicting behavioural intention (BI) and actual behaviour ( $A B)$. Notani also assessed the robustness of the TPB model. Notani used a search of ABI Inform, Psychological Abstracts, Psychlit databases, and references in published articles, thus obtaining 36 articles. In terms of findings, Notani reported that the TPB model had "performed well, with perceived behavioural control $[\mathrm{PBC}$ ] serving as an antecedent to both behavioural intention $[\mathrm{BI}]$ and [actual] behaviour [AB]" (p. 247). He also revealed that, PBC "is a stronger predictor of [actual] behaviour $[A B]$ when it (a) is operationalised as a global (vs. belief-based) measure; (b) is conceptualised to reflect control over factors primarily internal (vs. external) to an individual, and (c) is used for nonstudent (vs. student) samples and familiar (vs. unfamiliar) behaviour" (p. 247).

\section{Technological Pedagogical Content Knowledge Framework}

Mishra and Koehler (2006) developed the Technological Pedagogical Content

Knowledge (TPACK) framework depicted in Figure 8, as cited by Willermack, S. (2018).

Figure 8: The TPACK framework

Source: Mishra \& Koehler (2006), page 1025, Figure 4. 




The domains are content knowledge (CK), pedagogical knowledge (PK) and technological knowledge (TK). Mishra and Kohler (2006) defined CK as knowledge about the actual subject matter that is to be learned or taught. Mishra and Koehler observed that a teacher must know and understand the subject that he/ she teaches, including knowledge of central facts, concepts, theories, and procedures if the teacher is to integrate technology in teaching.

\section{Research Methodology}

In this research, a qualitative research methodology will be used in order to fulfil the objectives of this study. The choice of the qualitative research methodology in this research is guided by the underlying Interpretivist paradigm that seeks to understand the thought process of respondents in a certain context and generate new concepts or theories. According to Willig (2001) as cited by Hossain (2011), qualitative research is mostly concerned about contextual meaning which blends well with the world views of the Interpretivists that there are multiple realities that exist and have to be studied in contexts. The purpose of the qualitative study was to review the Information Technology framework for institutional University performance, and determine how technology was being integrated in the teaching/learning process in a university setting. It is envisaged to develop a technology roadmap for business administration of a university setting.

In this research, the case will be selected state Universities. The case study has the following strengths:

* there is room for flexibility in research questions to be used as well as the data collection methods

* case studies have strong processes for the formulation of new theories

* they have the capacity to give understanding to causes of complexities

There is need to understand institutional university performance which can be enhanced by the effective use of IT integration. This research intends to dig deep and bring forth the complicated University Institutional performance from both an administrative and teaching/learning perspective. 
A survey was conducted at selected national Universities to ascertain the technological gap analysis with respect to University Institutional performance and the teaching/learning process. Interviews were used to solicit information from respondents and to aid questionnaires for the Case Study. In this research, unstructured interviews were held will be done in order to ascertain the University Institutional performance and technological gap at the selected national Universities.

\section{Results and Analysis}

Technological Gap Analysis on Institutional University Performance

A survey was conducted at selected Zimbabwean institutions of higher learning to ascertain the technological gap analysis with respect to institutional university performance and the teaching/learning process.

The purpose for the Focus Group discussion was to research and identify the technological gap in business administration and the teaching/learning process in a typical Zimbabwean University. The main research question was to ascertain the technology gap in the business administration and the teaching/learning process of a university setting. The Case Study survey was conducted for the selected Zimbabwean Universities. The Focus Groups were derived from 11 Groups of Masters students at the University of Zimbabwe in the 2021 cohort who then were tasked to conduct surveys and interview the management of various Universities.

\section{Responses by Group}

\begin{tabular}{|l|l|}
\hline $\begin{array}{l}\text { GROUP: } \\
\text { INSTITUTI } \\
\text { ON }\end{array}$ & GROUP RESPONSE TO THE TECHNOLOGICAL GAP \\
\hline $\begin{array}{l}\text { 3: Lupane } \\
\text { State } \\
\text { University }\end{array}$ & $\begin{array}{l}\text { The purpose of the study was to assess the technological gap in the business } \\
\text { administration and the teaching/learning process of a University in Zimbabwe. The } \\
\text { Focus Group adopted a descriptive survey design. The key results from the survey } \\
\text { done for this selected University are as follows: }\end{array}$ \\
$\begin{array}{l}\text { 1. Information Technology in Education } \\
\text { Information Technology used in education was a combination of the processes and } \\
\text { tools involved in addressing the educational needs and problems by using } \\
\text { computers and other related electronic resources and technologies. The University } \\
\text { used IT in the delivery of all its educational programmes. }\end{array}$
\end{tabular}

\section{The Technology Acceptance Model (TAM)}

The TAM proposed by Fred D. Davis (1989) is centred on the notion of the individual's beliefs about usefulness and ease of use are the major determinants of adoption and use of Information Systems in any organizations. The TAM model guided the adoption and implementation of technologies for both business administration and the teaching/learning process.

\section{Computer Self-Efficacy}

All staff members were directed to learn how to use computers for various functions or duties they carry out. In this way individuals are able to exercise 


\begin{tabular}{|c|c|}
\hline & 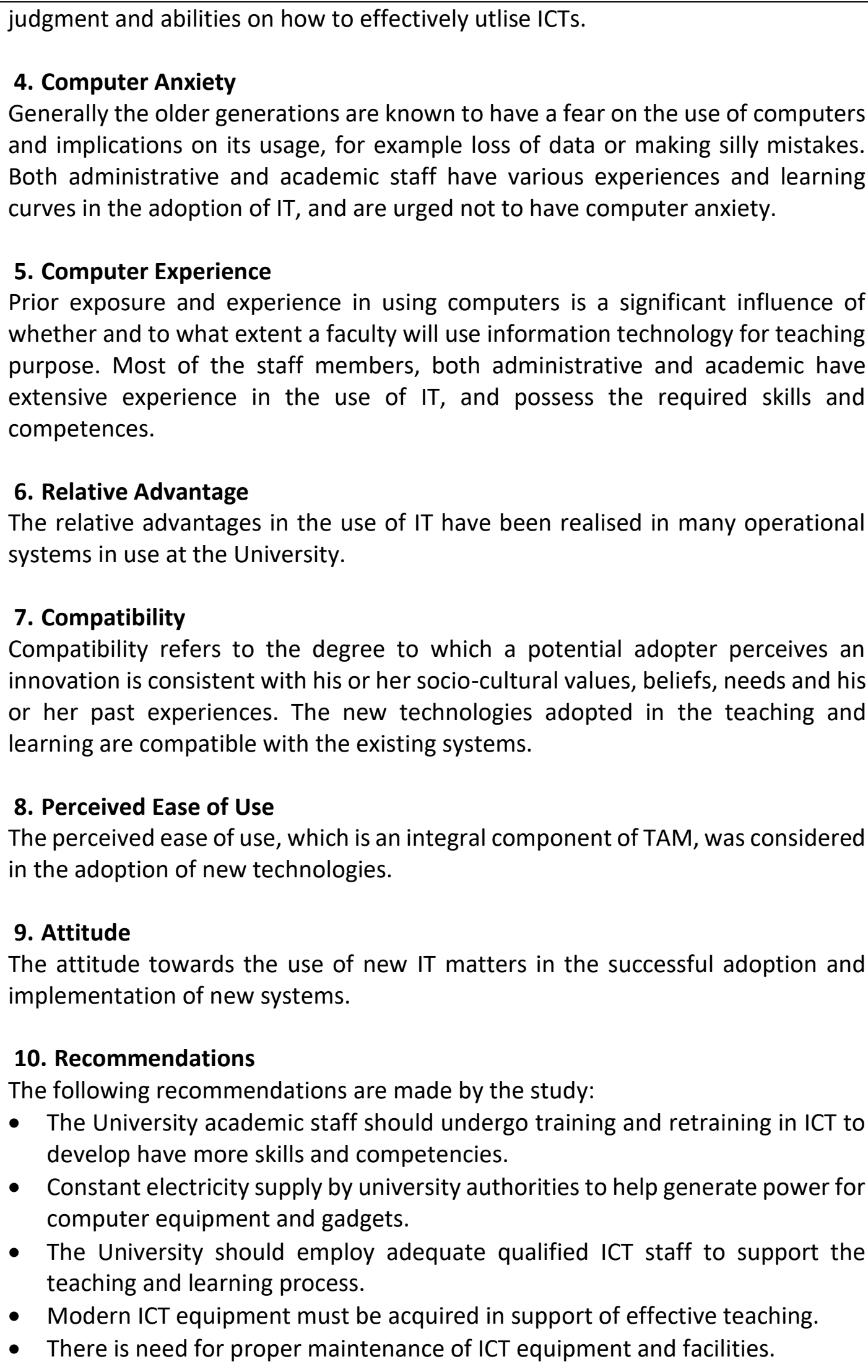 \\
\hline $\begin{array}{l}\text { 10: } \\
\text { University } \\
\text { of }\end{array}$ & $\begin{array}{l}\text { The Zimbabwe Council of Higher Education, which controls the basic qualification } \\
\text { structure of academic programs in higher education institutions, directed the } \\
\text { reform of curriculum content and assessment of all national universities. Higher }\end{array}$ \\
\hline
\end{tabular}




\begin{tabular}{|c|c|}
\hline Zimbabwe & 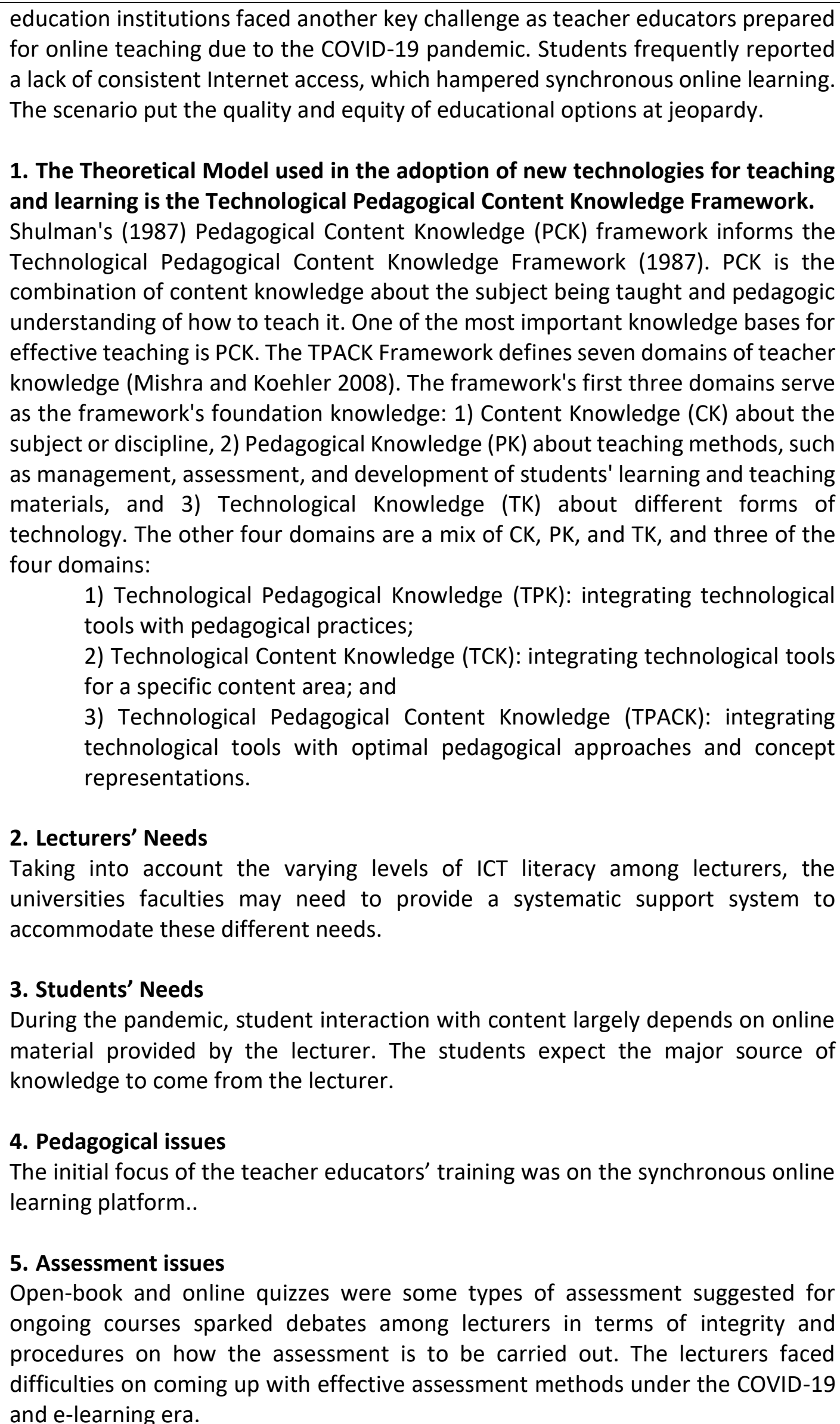 \\
\hline
\end{tabular}




\begin{tabular}{|c|c|}
\hline & $\begin{array}{l}\text { 6. Teaching practicum issues } \\
\text { Teaching of practicum, often used by student teachers, was difficulty to setup. } \\
\text { These students who have less exposure to practising strategies and managing } \\
\text { classroom disciplinary issues could possibly face difficulties later in their career. } \\
\text { 7. Administrative Issues } \\
\text { Other challenges have arisen as a result of technological adoption, the effects of } \\
\text { which have yet to be completely examined. Changes in the makeup of the teaching } \\
\text { pool, changes in the profile of who is enrolled in our courses, and, most } \\
\text { importantly, changes in the costing and economics of course delivery are all part } \\
\text { of this. The key administrative issues under consideration in reducing the } \\
\text { technological gap include the following: } \\
\text { a. Expanding The Pool Of Teachers } \\
\text { b. Expanding the Pool of Students } \\
\text { c. The Cost of Education }\end{array}$ \\
\hline $\begin{array}{l}11 \\
\text { NUST }\end{array}$ & $\begin{array}{l}\text { The main aim was to establish the challenges of ICT use in the administration of } \\
\text { National University of Science and Technology in order to identify the potential of } \\
\text { integrating ICT in university administration for effective and efficient service } \\
\text { delivery. } \\
\text { 1. The Expectancy Theory } \\
\text { The Expectancy Theory guides individuals on how to make choices and urges } \\
\text { individuals to believe that the reward is worth the effort needed. } \\
\text { 2. Drive for adoption of ICT at Institutions } \\
\text { University administration plays a very crucial role in change management in the } \\
\text { adoption of ICT for administrative purposes which would involve both learning and } \\
\text { unlearning to overcome organisational culture and other barriers. Change not only } \\
\text { involves learning, but unlearning something that is already present and well- } \\
\text { integrated into the personality and social relationships of the individuals. } \\
\text { 3. The strategic role of ICT at Tertiary Education } \\
\text { Perception of ICT is of strategic importance for an organization due to its influence } \\
\text { on the post-grades and working efficiency of the students. } \\
\text { 4. Conclusions and Recommendations } \\
\text { 4.1 ICT use at NUST } \\
\text { This study identified ICT gaps relevant to students and administration staff at } \\
\text { NUST. These gaps were: Lack of ICT facilities, poor WIFI signals, Library opening } \\
\text { hours and closing hours to access the computers and lack of knowledge on how to } \\
\text { research through computers. } \\
\text { The researcher observed that, out of the afore mentioned constraints extracted in } \\
\text { the study, none of them contained academically oriented factors such as } \\
\text { curriculum, research expertise, teaching capacity and qualifications of faculty staff. } \\
\text { The researcher also noted that unlike other Universities in Zimbabwe, NUST was } \\
\text { the only one working towards the adoption of ICT on all campuses. }\end{array}$ \\
\hline
\end{tabular}




\begin{tabular}{|c|c|}
\hline & $\begin{array}{l}\text { 4.2 Overall student and staff perception of ICT adoption at NUST } \\
\text { Findings were unsettling in that there were more students (28.6\%) that had a } \\
\text { negative opinion of ICT adoption at NUST than those that had a positive opinion } \\
\text { (23.1\%). Perceptions of quality have been found to be important influences on } \\
\text { students' post enrolment word-of-mouth communications (Ben, 2007;). }\end{array}$ \\
\hline $\begin{array}{l}\text { 6: } \\
\text { University } \\
\text { of } \\
\text { Zimbabwe }\end{array}$ &  \\
\hline
\end{tabular}




\begin{tabular}{|c|c|}
\hline & $\begin{array}{l}\text { It is important to note that there are various recent technologies in teaching and } \\
\text { learning as well as in administration that the university must be by now have } \\
\text { embraced. For teaching and learning these include E-readers, Interactive } \\
\text { Whiteboards and Flipped classrooms. In administration, there is need for } \\
\text { Enterprise Resource Planning (ERP). } \\
\text { In conclusion, it is recommended that the university need to invest more in ICT } \\
\text { technologies in order to reduce or eradicate the ever-increasing gaps. ICT } \\
\text { technologies makes teaching/learning and administration a lot easier if embraced } \\
\text { and employed more efficiently and effectively. }\end{array}$ \\
\hline $\begin{array}{l}\text { 1: } \\
\text { University } \\
\text { of } \\
\text { Zimbabwe }\end{array}$ & $\begin{array}{l}\text { The administration part of a university was manually based in the past decades } \\
\text { using more paperwork. Libraries were mainly filled with hard copies of books, } \\
\text { students were doing their registration using manually generated forms, and } \\
\text { applications were done via post. However, with emergence of ICT, everything has } \\
\text { been revolutionised and is being done online. } \\
\text { 1. Relevance of ICT Resources in School Administration. } \\
\text { v. The use of ICTs helps improve the quality of education: ICTs enhance learner } \\
\text { motivation, engagement and teacher training. } \\
\text { vi. Sharing knowledge: Students can easily share knowledge, learning materials, } \\
\text { doucmentts and slides even among the geographically dispersed learners. } \\
\text { vii. ICTs help prepare individuals for the workplace: ICTs used in learning and } \\
\text { teaching process equips students for the workplace and the global village. } \\
\text { viii. Access to remote learning resources: Teachers and learners can access learning } \\
\text { materials and resources from anywhere in the world. } \\
\text { ix. Processing knowledge: Students and teachers can use ICT as part of a creative } \\
\text { process where they have to consider more carefully the information which } \\
\text { they have about a given subject.. } \\
\text { 2. Learning and content management systems } \\
\text { Learning management systems (LMS) and Content management systems (CMS) } \\
\text { used to track student attendance and progress, post and share content and } \\
\text { communicate through features such as wikis, blogs and discussion forums (Trotter, } \\
\text { 2008, as cited in Bakia, 2011, p. } 28 \text { ). } \\
\text { 3. Computer literacy } \\
\text { Basic compute literacy is required in both business administrative functions and } \\
\text { the teaching and learning process, including rigorous university study. } \\
\text { multiple televisions in the home together with VCRs, CD players, etc. Thus } \\
\text { affordable during that time. }\end{array}$ \\
\hline
\end{tabular}




\begin{tabular}{|c|c|}
\hline & $\begin{array}{l}\text { generation was well prepared for continuing professional development programes } \\
\text { offered by Universities. } \\
\text { 6. Generation Y/Millennials } \\
\text { The majority of this generation was probably born between } 1981 \text { and } 1999 \text {. This is } \\
\text { the generation that has produced critical drivers of technological innovations. } \\
\text { There is a generation gap between lecturers, admin personnel and students. The } \\
\text { students have grown up in a technologically advanced environment than the older } \\
\text { lecturers and some admin personnel at university. So the university management } \\
\text { should come up with staff training to equip their staff. Also funding of ICT } \\
\text { equipment is proving to be a challenge both at institution level and the students. } \\
\text { The government has tried its best to buy computers at universities and adopting } \\
\text { online platforms for administrative purposes where students are now accessing } \\
\text { portals to register, pay fees, access their results, download modules and do online } \\
\text { lectures. So the gap is slowly closing but there is need for more funding to keep up } \\
\text { with global trends. }\end{array}$ \\
\hline $\begin{array}{l}\text { 9: } \\
\text { Zimbabwe } \\
\text { Open } \\
\text { University }\end{array}$ & $\begin{array}{l}\text { Technology gap in business administration and the teaching process in a typical } \\
\text { Zimbabwean University setup: A case Study of Zimbabwe Open University (ZOU) } \\
\text { One key recommendation is full participation of relevant stakeholders in policy } \\
\text { formulation, training and capacitation of ICT human resources and many other } \\
\text { action points drawn from the study. The study also recommends that Universities } \\
\text { like ZOU needs to put in place proper e-learning policies and procedures, adequate } \\
\text { infrastructure for the students and make them fast and accessible at all times. ZOU } \\
\text { should upgrade the ICT learning materials and the MyVista platform which is used } \\
\text { by all students and staff. These barriers include lack of Lecturer ICT skills; lack of } \\
\text { Lecturer confidence; lack of pedagogical Lecturer training; lack of suitable } \\
\text { educational software; limited access to ICT; rigid structure of traditional education } \\
\text { systems; restrictive curricula, etc. } \\
\text { ICT is fast becoming the centre of global social and economic transformation on } \\
\text { top of being a strategic resource and pillar of every economic activity. An ICT policy } \\
\text { is key to ensuring that ICT investments are effective, acceptable and efficient. } \\
\text { Furthermore, an ICT policy standardizes, directs and controls the use of ICTs in any } \\
\text { area of concern. } \\
\text { There is a theoretical model for Information administration that has been } \\
\text { formulated, and is shown below: }\end{array}$ \\
\hline
\end{tabular}




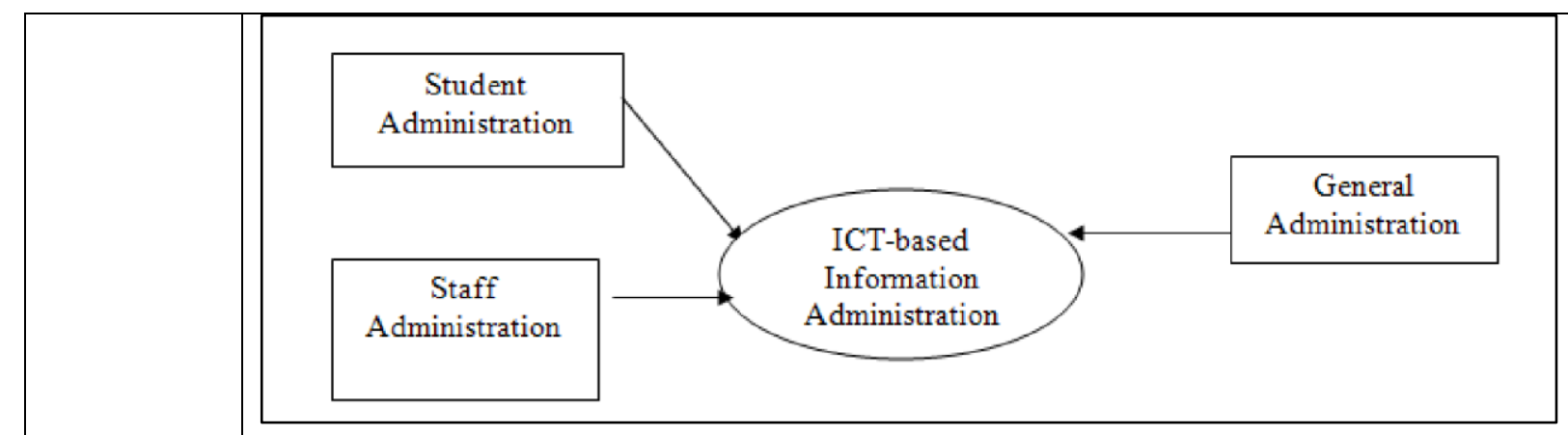

Figure: A model of ICT Based Administrative services in a University setup (Krishnaveni and Meenakumari, 2010)

The following are some of the areas where ICT can be applied in a university setup environment at ZOU.

- Administration of Student Accounts/ Data -the students' management system at ZOU is merely a basic database and most of the stuff is done manually hence a delay in processing data

- Website and Online Marketing systems - ZOU is doing the minimum in terms of marketing online on their websites as well as on social. Moreover their website has little functionality.

- Payroll and Financing Account - There is not a dedicated system for the internal payroll for workers like general hands.

- Library System - In this day and age the University is still partly using Hard copies. Their ZLibrary system has limited content and sometimes it is down.

- General Administration - Issues like payment Plan application are still being done on paper.

Procurement and store management

However there are also challenges associated with implementing some of the above mentioned systems which include:

i. Economic inflation - currently Zimbabwean economy is not stable hence developments are difficulty to implement

ii. Lack of funding - lack of adequate funding result in the organization implementing cheap and poor systems which may be outdated.

iii. Technological changes - Technology is ever changing hence keeping up with the global trends is difficulty in this part of the world where we are always lagging behind.

iv. Lack of infrastructure - Infrastructure is always a drawing back factor since issues like network connectivity affects usage of ICT and the institutions have little or no control over it since they depend on service providers.

Therefore, ICT is now a necessity in business administration since this will help in achieving set targets more effectively. Some of the advantages of integrating ICT in business Administration are:

- Increased Productivity: ICT improves productivity of workers by automating processes.

- Greater and Virtual Collaboration: Working from home supported by using 


\begin{tabular}{|c|}
\hline  \\
\hline
\end{tabular}




\begin{tabular}{|c|c|}
\hline & $\begin{array}{l}\text { innovative by upgrading the ICT materials and their E-Learning platforms such as } \\
\text { MyVista platform as well as on ZLibrary. Training of all stakeholders in the use of } \\
\text { these systems should be prioritised as this will enhance productivity. The } \\
\text { Zimbabwean government should also invest in E-learning for Tertiary as they are } \\
\text { doing in Secondary Schools. }\end{array}$ \\
\hline $\begin{array}{l}4 \\
\text { Zimbabwe } \\
\text { an } \\
\text { University } \\
\text { of } \\
\text { Technolog } \\
\text { y: The Case } \\
\text { Study of } \\
\text { Technolog } \\
\text { y } \\
\text { Innovation } \\
\text { Hub }\end{array}$ & $\begin{array}{l}\text { Zimbabwean University of Technology: The Case Study of Technology Innovation } \\
\text { Hub. } \\
\text { From a Technology Innovation Hub perspective, the technology gap in the business } \\
\text { administration and the teaching/learning process in Zimbabwean University is } \\
\text { highlighted below. } \\
\text { One of the greatest challenges in ICT use in the business administration and in } \\
\text { education circles is balancing educational goals with economic realities. } \\
\text { Technology gap in the business administration and the teaching/learning process } \\
\text { in Zimbabwean University is largely driven by lack or absence of strong leadership. } \\
\text { Learning materials development creates a missing link in the technology part in } \\
\text { business administration and teaching field. Original educational content must be } \\
\text { created such as radio programs, DVDs, etc. }\end{array}$ \\
\hline $\begin{array}{l}2 \\
\text { Ministry of } \\
\text { Higher and } \\
\text { Tertiary } \\
\text { Education }\end{array}$ & $\begin{array}{l}\text { The Zimbabwean Ministry of Higher and Tertiary Education recently introduced } \\
\text { Education } 5.0 \text { which focuses on five pillars which are research, teaching, } \\
\text { community service, innovation and industrialization. The curriculum is a shift from } \\
\text { preparing students for white collar and blue-collar jobs to preparing them for job } \\
\text { creation by using generated knowledge for the creation of goods and services } \\
\text { (Muzira and Bondai, 2020). The technological pedagogical content knowledge } \\
\text { model was used to evaluate the information and skills that academic staff } \\
\text { members must possess, with an emphasis on technology knowledge (TK) and } \\
\text { technical pedagogical knowledge (TPK), which are essential in tele-education. } \\
\text { Framework for Discussion - TPACK } \\
\text { Shulman (1987) defined seven domains of teacher knowledge in his Pedagogical } \\
\text { Content Knowledge - TPACK Framework (Mishra and Koehler 2008). The first three } \\
\text { domains of the framework serve as the framework's foundation knowledge: 1) } \\
\text { Content Knowledge (CK) about the subject or field, 2) Pedagogical } \\
\text { Knowledge about teaching techniques, such as managing, assessing, and } \\
\text { developing students' learning and teaching materials, and 3) Technological } \\
\text { Knowledge about various types of technology. The remaining four domains are a } \\
\text { combination of Content Knowledge, Pedagogical Knowledge, and Technological } \\
\text { Knowledge, with three of them: } \\
\text { 1) Technological Pedagogical Knowledge: integrating technological tools with } \\
\text { pedagogical practices; } \\
\text { 2) Technological Content Knowledge: integrating technological tools for a specific } \\
\text { content area; and } \\
\text { 3) Technological Pedagogical Content Knowledge: integrating technological tools } \\
\text { with optimal pedagogical approaches and concept representations. }\end{array}$ \\
\hline
\end{tabular}




\begin{tabular}{|c|c|}
\hline & $\begin{array}{l}\text { TPACK has previously functioned as a lens through which teacher educators and, } \\
\text { to a lesser extent, student teachers on their school-based teaching practice } \\
\text { assessed online teaching experiences. } \\
\text { Teaching and Learning Aspects } \\
\text { Considering the various degrees of ICT literacy among professors, university } \\
\text { faculties may need to create a systematic support structure to meet these various } \\
\text { demands. Knowledge of technology and, in particular, its use in an online setting } \\
\text { (including the ability to use hardware, software, cloud computing, and web } \\
\text { applications became a necessity for coping with the transition to online teaching } \\
\text { and learning). } \\
\text { The students suggested that student-lecturer interaction should occur through } \\
\text { fast response and convenience, technology tools such as sending messages } \\
\text { through mobile applications instead of using email. } \\
\text { Lecturers need to accept that it is okay to communicate through WhatsApp, } \\
\text { because, it is difficult to communicate through email' (Student B). }\end{array}$ \\
\hline $\begin{array}{l}7 \\
\text { University } \\
\text { of } \\
\text { Zimbabwe }\end{array}$ & $\begin{array}{l}\text { The technology gap in the business administration and the teaching /learning } \\
\text { process a case study of the University of Zimbabwe } \\
\text { 1. Stable Internet Access } \\
51 \% \text { of the respondents do not have fixed internet access in their homes. Most } \\
\text { however have access to mobile internet on their phones which is not too stable. } \\
\text { 2. Capacity } \\
64 \% \text { of the sample population can afford access to the internet, as some indicated } \\
\text { that access is part of their packages from work. For most data is an expensive } \\
\text { commodity thereby limiting possible activity on the internet. Some respondents } \\
\text { highlighted that they doubted the university has the infrastructures in place to } \\
\text { successfully support rapid digitalization of processes. } \\
\text { 3. Willingness } \\
55 \% \text { of the respondents are willing to do online teaching/learning. The } \\
\text { administrative staff indicated a willingness to have current systems digitalized such } \\
\text { as registration, payments to avoid physical contact with students especially in light } \\
\text { of the current Covid pandemic. } 45 \% \text { of the respondents however were not keen } \\
\text { on digitalization and e-learning as they feel some content requires face to face } \\
\text { interaction and they would not be able to fully commit in their personal spaces. } \\
\text { 4. Recommendation and Conclusion } \\
\text { The study also mentions that a large number of UZ staff lack IT gadgets like smart } \\
\text { phones and laptops. This study also recommends considering the perception of } \\
\text { instructors at the universities. Questionnaires must be administered on lecturers } \\
\text { and other administrative officers to showcase the usefulness of ICT in university } \\
\text { education. The study recommended the University executive to hold workshops }\end{array}$ \\
\hline
\end{tabular}




\begin{tabular}{|c|c|}
\hline & $\begin{array}{l}\text { and seminars for staff and students so that they will be conversant with the current } \\
\text { technologies. The study also recommends the university to procure data bundles } \\
\text { for its entire staff as well as its students. The university Human Resources } \\
\text { department was recommended to recruit qualified personnel with strong IT } \\
\text { background because nowadays people are working more on the internet using } \\
\text { various IT gadgets. }\end{array}$ \\
\hline $\begin{array}{l}12 \\
\text { Harare } \\
\text { Institute of } \\
\text { Technolog } \\
\text { y }\end{array}$ & $\begin{array}{l}\text { This research takes Harare Institute of Technology (HIT) as a case study and } \\
\text { presents gaps in business administration and the teaching/learning process. } \\
\text { 1. Efficient management of operations. } \\
\text { HIT is also involved in manufacturing, students as well as lectures design and } \\
\text { manufacture products on campus. However, there is a haphazard manner of } \\
\text { operations, as there is too much manual intervention; there is no proper planning } \\
\text { as to who uses the available few workshops and the resources and in turn there is } \\
\text { a delay in activities. Students also flock unnecessarily to these workshops and this } \\
\text { consumes their time that they actually would have spent doing something else. HIT } \\
\text { uses the APS Systems can be quickly integrated with an ERP software and so can: } \\
\text { - Create optimized schedules balancing production efficiency and delivery } \\
\text { - performance } \\
\text { - Maximize output on bottleneck resources to increase revenue } \\
\text { - Provide Institution-wide visibility to capacity } \\
\text { 2. Improble scenario data-driven decision making } \\
\text { The sparcity and the lack of data organisation has led to delayed decision making } \\
\text { and slow processes. Decisions like school fees hiking and programs on offcer can } \\
\text { be made quickly with availability of data and information and this has not been the } \\
\text { case with HIT since data cannot be siloed. There is too much multichannel } \\
\text { convergence in manual data processing and the only thing that can solve this is } \\
\text { omnichannel integration. } \\
\text { Technology and National University of Science and Technology as well as Bindura } \\
\text { technologition of seamless integration and communication with key stakeholders } \\
\text { processes take long and prospective students can go for a long time without being } \\
\text { replied and in a majority of cases can actually be replied after lectures have } \\
\text { commenced. }\end{array}$ \\
\hline $\begin{array}{l}8 \\
\text { University } \\
\text { of }\end{array}$ & $\begin{array}{l}\text { The proposition of this survey was, "What is the technology gap in the business } \\
\text { administration and the teaching or learning process of a university setting?" The } \\
\text { first is a usage gap. The second is an outcome gap. }\end{array}$ \\
\hline
\end{tabular}




\begin{tabular}{|c|c|}
\hline Zimbabwe & 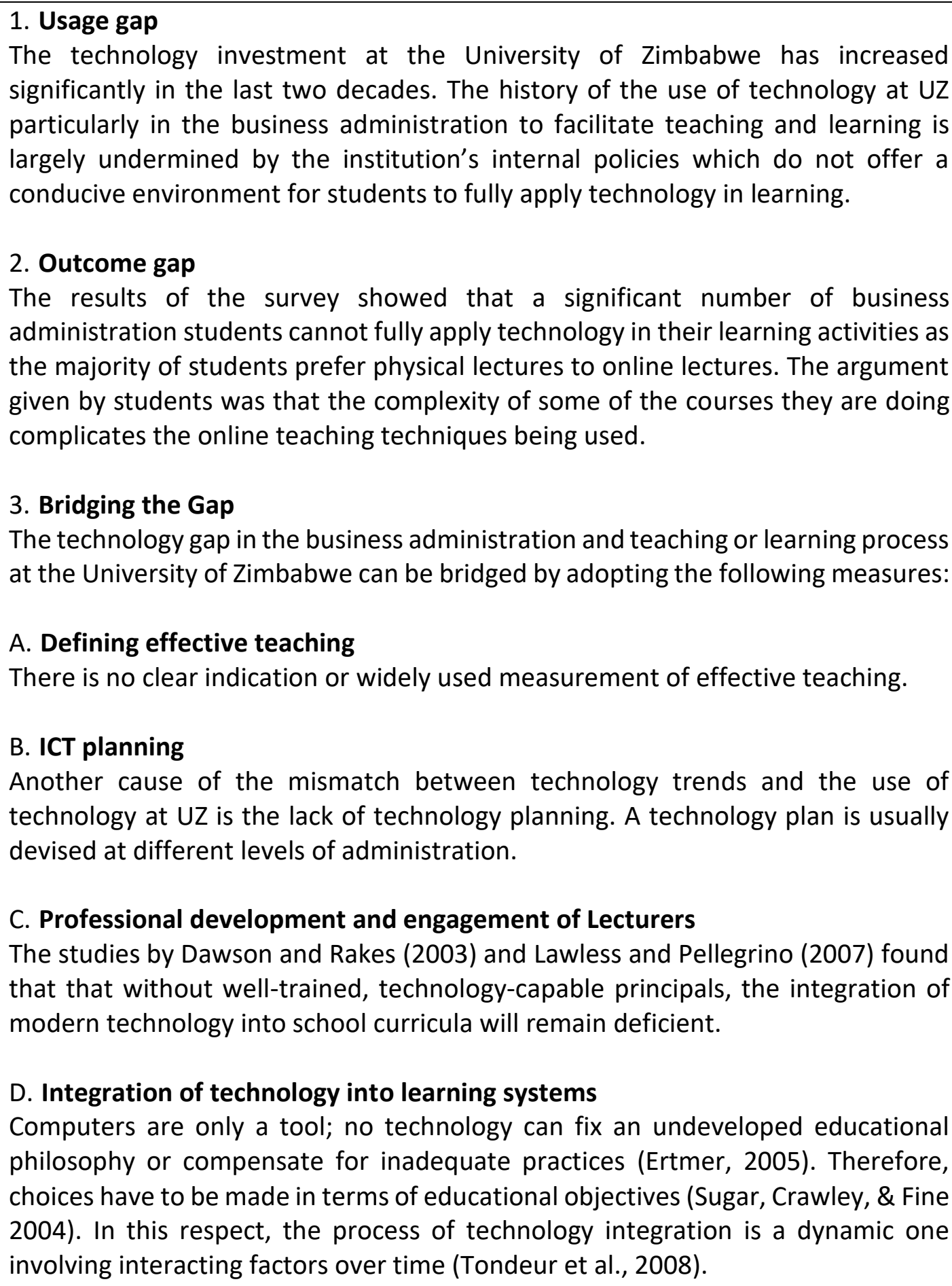 \\
\hline $\begin{array}{l}5 \\
\text { Great } \\
\text { Zimbabwe } \\
\text { University }\end{array}$ & $\begin{array}{l}\text { Findings indicate that lecturers' well-equipped preparation with ICT tools and } \\
\text { facilities is one the main factors in success of technology-based lecturing and } \\
\text { learning. It was also found that professional development training programs for } \\
\text { lectures also played a key role in enhancing students' quality learning. However, } \\
\text { ICT integration is not a one-step learning process, but it is a continual process of } \\
\text { learning that provides proactive lecturing-learning environment (Young, 2003). } \\
\text { Lecturers Belief on Technology-based Lecturing and Learning } \\
\text { The major barrier of the implementation was the lectures' belief as the lectures }\end{array}$ \\
\hline
\end{tabular}


are the person who implements the change in their lecturing and learning process. Lecturers' role is getting more important especially in usage of ICT in pedagogy which could increase the achievement of the students, their creativity and thinking skills.

Lecturers' Perception on Technology-based Lecturing and Learning

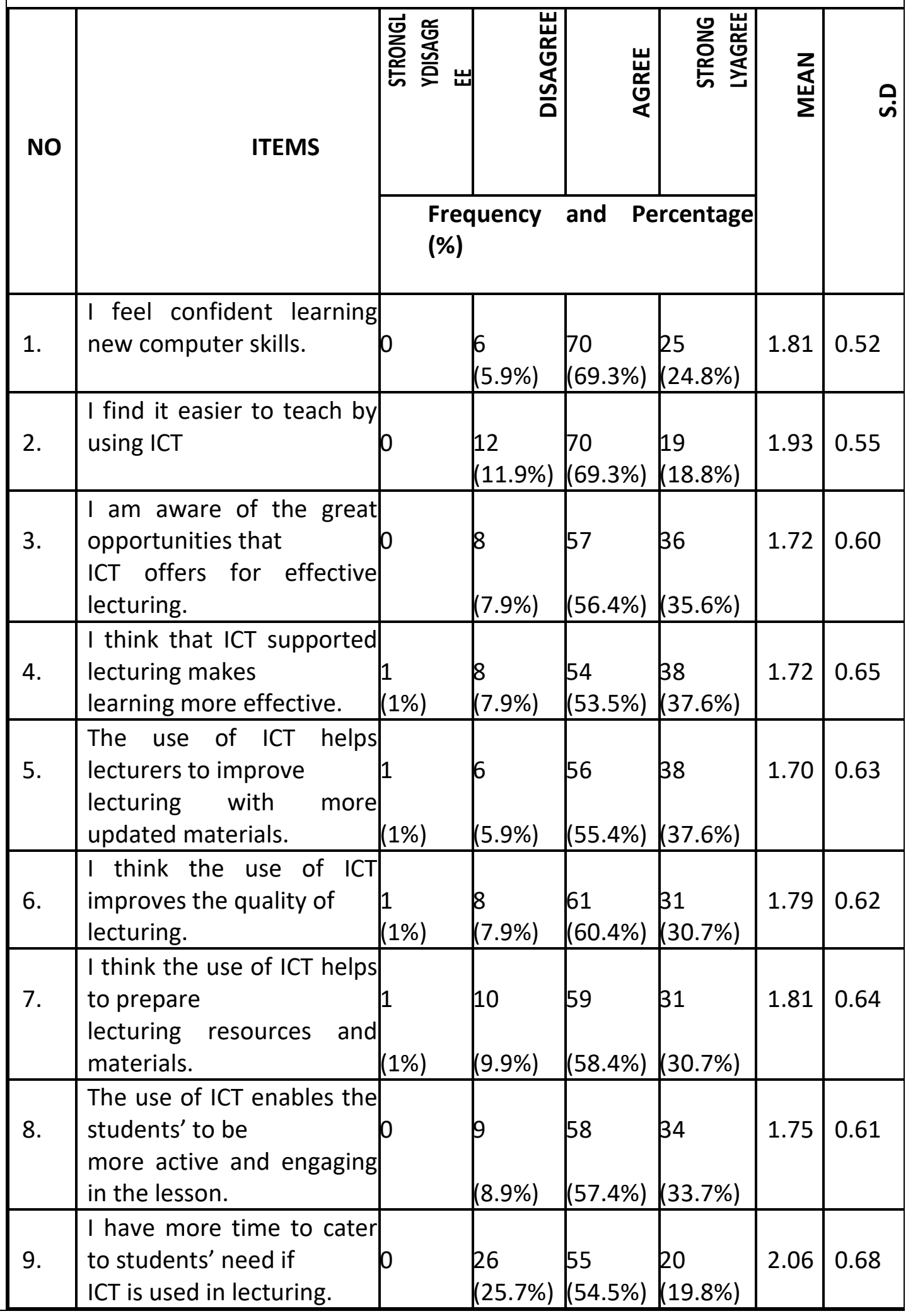




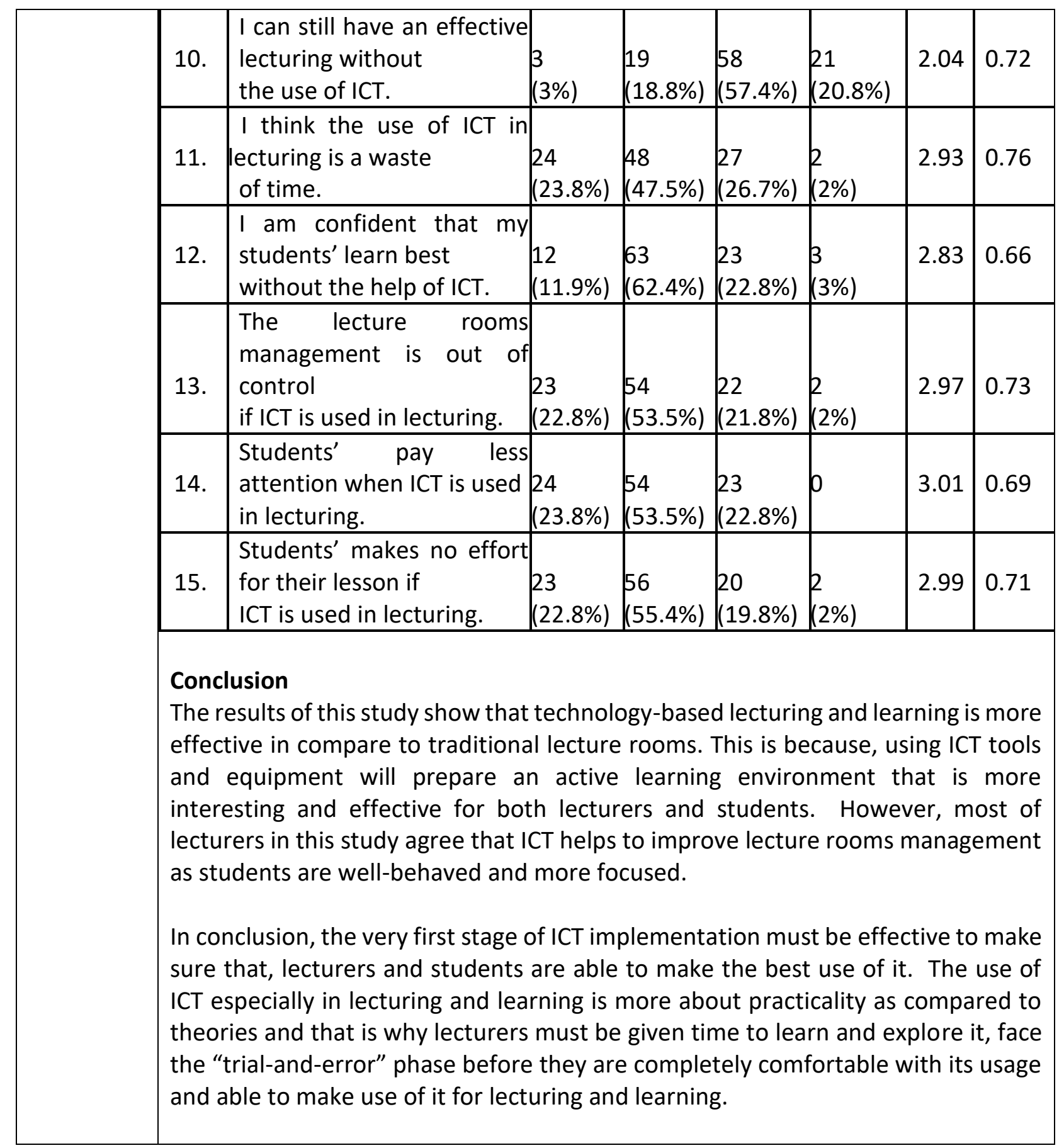

\section{Conclusion}

The purpose of the qualitative study was to review the Information Technology framework or University Institutional performance and determine how technology was being integrated in the teaching/learning process in a university setting. The research paper reviewed IT integ ation framework premised on ten theories.

ZIMCHE accredits only those University programmes that meet ZIMCHE's minimumagreed st andards. Information Technology integration is a very challenging complex process for a uni versity teaching and learning setting, particularly in a university environment that has had fi nancial limitations on investment in technology and where there has been limited skills and competences in the use of ICTs in support of teaching and learning.

One key recommendation is full participation of relevant stakeholders in policy formulation, 
training and capacitation of ICT human resources and many other action points drawn from $t$ he study.

The Zimbabwe Open University uses the MyVista technology platform for the teaching and learning process, and this is an excellent model to be used by many Zimbabwean universities. It was observed that the technology investment at the University of Zimbabwe has increased significantly in the last two decades.

The history of the use of technology at UZ particularly in the business administration to facili tate teaching and learning is largely undermined by the institution's internal policies which did not offer a conducive environment for students to fully apply technology in learning. Another cause of the mismatch between technology trends and the use of technology at UZ is the lack of technology planning.

The use of Information and Communication Technologies in the 21st century organizations $\mathrm{h}$ as a great impact on efficient management of operations, improved decision making capabili ties, leveraging competitive advantage, and facilitation of the IT Integration framework for a University Institutional performance setting in Zimbabwe with seamless integration and communication with key stakeholders.

\section{References}

Alshams, Y. A. A. B., Adaikalam, J., Karim, A. M., Hock, O. Y., \& Hossain, M. I. (2020). Application of Strategic Management Information System (SMIS) in the Ministry of Interior, UAE: Issues and Challenges. International Journal of Academic Research in Business and Social Sciences, 10(2), 346-361.

Abdullah, G. (2015). Technological innovations and banking; Journal of finance and economics. Vol. 6, No. 2, pp. 48-63.

Ali, A. (2010). Strengthening the satisfaction profit chain. Journal of service research. Vol. 2, No. 2, pp. 107-120.

Aypay, D., Derrick, T., Polite, N., and Tom, P. (2012). Innovations in retail banking. The Wharton School, University of Pennsylvania, Philadelphia.

Berman, D. S., Buczak, A. L., Chavis, J. S., and Corbett, C. L. (2019). "Survey of Deep Learning Methods for Cyber Security", Information 2019, 10, 122; doi:10.3390/info10040122.

Campanella, F., Del Giudice, M., Thrassou, A., \& Vrontis, D. (2020). Ambidextrous organizations in the banking sector: an empirical verification of banks' performance and conceptual development. The International Journal of Human Resource Management, $31(2), 272-302$.

Chattur, C. (2015). An empirical investigation of the Turkish consumers' acceptance of internet banking services; international journal of bank marketing. Vol. 19, No. 4, pp. 156-165.

Christensen, C. M. (1997). The Innovator's Dilemma: When New Technologies Cause Great Firms to Fail. Boston: Harvard Business School Press

Christensen, M., and Michael, E. R. (2003), The Innovator's Solution: Creating and Sustaining Successful Growth, Boston, MA: Harvard Business School Press.

Cooper, D. R., \& Schindler, P. S. (2011). Business Research Methods, 11th, edition. McGrawHill Publishing, Co. Ltd. New Delhi-India. 
Cresell, L. (2013). Commercial bank management. 4th Edition, Irwin/McGraw-Hill, Boston, USA.

Damsgaard, A. (2011). The relationship between Information and Communication Technology (ICT) adoption and management; information and management. Vol. 8, No. 39, pp.659671.

Ducey, E. (2014). An assessment of moral hazard and financial crisis and credit risk approaches; journal of competitiveness. Vol. 4, No. 2, pp. 69-84.

Durodolu, I. (2016). Success factors in E-channel; international banking community. The journal of consumer banking. Vol. 2, No. 22, pp. 88-99.

Garg, R. (2013). Survey research methods; revised edition. Beverly Hills, Sage publications.

Gheyas, I. A., \& Abdallah, A. E. (2016). Detection and prediction of insider threats to cyber security: A systematic Literature Review and Meta-Analysis., Big Data Analytics (2016) 1:6.

Gouws, W., and George, R. (2011). Inter-organizational alliances and the performance of firms; a study of growth and innovation rates in a high technology industry. The strategic journal of management, pp. 791-811.

Hashem, I. A. T., Yaqoob, I., Anuar, N. B., Mokhtar, S., Gani, A., \& Ullah Khan, S. (2015). The rise of "big data" on cloud computing: Review and open research issues. In Information Systems. https://doi.org/10.1016/j.is.2014.07.006

Kantarcioglu, M., \& Xi, B. (2016). Adversarial Data Mining: Big data meets cybersecurity, CCS, 16 October 24-28, 2016, Vienna, Austria.

Kim, C., and Keller, J. M. (2011), "Towards technology integration: the impact of motivational and volitional email messages", Educational Technology Research and Development, 59(1), 91e111, https://eprints.lancs.ac.uk/id/eprint/90131/1/The_Technology_Integration_Model.pf

King, S., Hicks, T., and Reeves, J. (2014). Small Business Success in the Cloud, Intuit. [Retrieved on 7 October] from https://www.slideshare.net/Intuitlnc/future-of-smb-for-slidesharev $2 / 1$

Kuffour, S., (2017), The impacts of ICT on Modern World Business, Munich, GRIN Verlag, https://www.grin.com/document/418223

Kumar, S., and Shrama, S. (2019), Artificial Intelligence in Disaster Management, IOSR Journal of Computer Engineering (IOSR-JCE), Volume 21, Issue 3.

Lei, G., Liu, C., Li, Y., Chen, D., Guo, Y., Zhu, J. (2019). Robust Design Optimization of a HighTemperature Superconducting Linear Synchronous Motor Based on Taguchi Method. IEEE Transactions on Applied Superconductivity, 29(2), 1-6.

Makanyeza, C. (2016), Determinants of consumers intention to adopt mobile banking services in Zimbabwe, International Journal of Bank Marketing Vol. 35 No. 6 pp. 9971017, http://www.emeraldinsight.com/0265-2323.htm

Mishra, S., Raut, R. D., Narkhede, B. E., Gardas, B. B., Priyadarshinee, P. (2018). To investigate the critical risk criteria of business continuity management by using analytical hierarchy process. Int. J. Manag. Concepts Philos. 11 (1), 94-115.

Mojambo, G. A., Tulung, J. E., \& Saerang, R. T. (2020). The influence of top management team (TMT) characteristics toward Indonesian banks financial performance during the digital era (2014-2018). JMBI UNSRAT (Jurnal IImiah Manajemen Bisnis dan Inovasi Universitas Sam Ratulangi). 7(1).

Moore, F. T. (2016). Financial institutions privatization and performance; Journal of finance and banking. Vol. 29, No. 8, pp. 55-79. 
Pu, C., and Kitsuregawa, M. (2019), Technical Report No. GIT-CERCS-13-09; Georgia Institute of Technology, CERCS.

Richard, P. J., Devinney, T. M., Yip, G. S., \& Johnson, G. (2009). Measuring organizational performance: towards methodological best practice. Journal of Management, 35(3), 718-804.

Rogers, E. M. (2003). Diffusion of innovation. 5th edition. New York: Simon \& Schuster, Inc.

Samui, P., Kim, D., \& Ghosh, D., (2018), Integrating Disaster Science and Management Global Case Studies in Mitigation and Recovery.

Sarker, I. H., Kayes, A. S. M., Badsha, S., Alqahtani, H., Watters, P., \& Ng, A. (2020). Cybersecurity data science: an overview from machine learning perspective. Journal of Big Data. https://doi.org/10.1186/s40537-020-00318-5

Scherer, R., Siddiq, F., \& Tondeur, J. (2019). The technology acceptance model (TAM): A metaanalytic structural equation modeling approach to explaining teachers' adoption of digital technology in education. Computers \& Education, 128, 13-35. Retrieved from https://doi.org/10.1016/J.COMPEDU.2018.09.009

Siti, N. M. M., Sazilah, S., \& Norasiken, B. (2017). An Analysis of Gamification Elements in Online Learning To Enhance Learning Engagement. 6th International Conference on Computing \& Informatics.

Tomatzky, L., \& Fleischer, M. (1990). The process of technology innovation, Lexington, MA, Lexington Books.

Venkatesh, V., Morris, M., Davis, G., \& Davis, F. (2008). User Acceptance of Information and Communications Technology: Toward a Unified View, MIS Quarterly 27 (3), pp.425-478.

Wilson, B. M. R., Khazaei, B., \& Hirsch, L. (2015). Enablers and barriers of cloud adoption among Small and Medium Enterprises in Tamil Nadu. In: 2015 IEEE International Conference on Cloud Computing in Emerging Markets (CCEM) (pp. 140-145). IEEE

Willermack, S. (2018), "Technological Pedagogical and Content Knowledge: A Review of Empirical Studies Published From 2011 to 2016", 2018, Journal of Educational Computing Research,Vol. 56(3) 315-343, https://journals.sagepub.com/doi/full/10.1177/0735633117713114

Yang, C., Yu, M., Hu, F., Jiang, Y., \& Li, Y. (2017). Utilizing Cloud Computing to address big geospatial data challenges. Computers, Environment and Urban Systems. https://doi.org/10.1016/j.compenvurbsys.2016.10.010. 